\title{
Indledning
}

\section{Overskridende metoder}

\section{Af Dorthe Staunas og Eva Bendix Petersen}

Hvad er det, vi skal overskride og bvorfor? Har det en teoretisk og metodisk pointe at flytte granser og demarkationslinjer? Ev det overskridende i forbold til de subjekter og objekter, der forskes $i$ ? Og bvilke etiske og moralske dilemmaer melder der sig, nair markeringer forstyrres, forrykkes og nedbrydes? Er kriteriet for om forskning er god nok, at den bave er overskridende? Hvor overskridende kan og vil man vere?

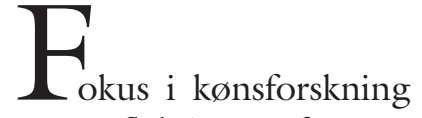
har i de senere år være refleksioner af teoretisk tilsnit, hvor et af de vigtigste bidrag er at dekonstruere binære (køns-)kategorier og i stedet udforske mangfoldighed og kompleksitet. Den tværfaglige kønsforskning har blandt andet betydet en åbenhed overfor at lade sig inspirere af forskelligartede teorier og metoder. Åbenhed og mangfoldighed har afstedkommet en række eksperimenterende og nytænkende metodologiske bestræbelser, som i dag ofte går under betegnelser som overskridende metoder (transgressive methodology) og i andre sammenhænge dekoloniserende metoder. Det er blevet nøgleord i en del nyere feministisk forskning, og det er begreber, der har inspireret til årets sidste nummer af Kvinder, køn o forskning. 1

Vi bringer her tre artikler, et interview og et debatindlæg, der byder på metodiske overskridelser. Den første artikel "Against Empathy, Voice and Authenticity" er forfattet fra et feministisk, poststrukturalistisk ståsted af Patti Lather og diskuterer primært overskridelser på det metateoretiske og formidlingsmæssige område. Statistiker Inge Henningsen og psykolog Dorte Marie Søndergaard tager ligeledes det metateore- 
tiske niveau under behandling $\mathrm{i}$ deres artikel "Forskningstraditioner krydser deres spor - "Kvalitative og kvantitative sociokulturelle empiriske forskningsmetoder". De eksemplificerer deres tanker ved at gennemgå vigtige trin $\mathrm{i}$ hhv. kvantitative $\mathrm{og}$ kvalitative forskningsprocesser og vidensproduktion er og ser herigennem på ligheder og forskelle. Antropolog Cathrine Hasses artikel "Overvejelser over deltagerobservation - sexede astronomer og kønnede læreprocesser" gentænker deltagerobservation som et metoderedskab, og Hasse undersøger, hvordan en reflekteret brug af forskersubjektets gradvise indlemmelse i et praksisfællesskab kan informere forskningsmaterialet. Til slut bringer vi anden del af Nina Lykke, Randi Markussen og Finn Olesens interview med Donna Haraway. Det er en samtale med Haraway, der spænder over mange af de samme emner, som Lathers artikel men i det særlige harawayske post-poststrukturalistiske univers. I debatsektionen finder man kommunikations- og kønsforsker Christina Hee Petersens refleksioner over "Det farlige og befriende vi" skrevet fra et sted midt i og udenfor kønsforskningen i Danmark og midt i og udenfor poststrukturalismen.

Metodenummeret rummer metoder og forfattere, vi selv er meget inspirerede af $\mathrm{i}$ vores forskning om hhv. videnskabelighed, kvalitet og køn (Bendix Petersen) og dialogisk etnicitets- og kønsforskning med børn/unge (Staunæs). For os har disse metoder betydet kvantespring og forstyrrelser i vores forståelser af sociale kategorier som køn og etnicitet og af forskningens positions- og magtstrukturer. Det er samtidig tekster med et meget højt abstraktionsniveau, og vi har derfor som noget nyt $\mathrm{i}$ Kvinder, køn \& forskning forsøgt os med en indledning, der gen-skriver nogle af de udfordringer og problematikker, der tages op i teksterne. ${ }^{2}$ Samtidig med at vi citerer pointerne på ny, er vi også med til at skabe betydninger udfra teksterne på måder, som måske har ligget udenfor forfatternes inten- tioner, men som trænger sig på fra hver vores forskningspraksisser. Ved at skrive rundt om, imellem og videre på teksterne er det vores ide at udsætte den relative fiksering det er at skrive en artikel. Derigennem forstyrrer vi de helstøbte artikler og åbner (forhåbentlig) op for et rum, hvor læseren også kan inviteres til en dialog om overskridende metoder.

\section{POST-POSITIVISTISKE OVERSKRIDELSER}

Metodisk opfindsomhed kan findes indenfor mange forskellige forskningstraditioner. Vi har valgt at koncentrere os om et udvalg af overskridende metoder, der er udviklet indenfor forskellige typer af, det man kan kalde, feministisk postpositivistisk tænkning. Postpositivisme er blevet karakteriseret på mange måder, og der er mange forskellige teoretiske, analytiske og metodiske positioneringer, man kan fremsætte som eksempler på fænomenet, f.eks. poststrukturalisme, postmodernisme, diskursanalyse, social konstruktionisme, forskellige udgaver af sociokulturel tænkning, Science and Technology Studies, post-poststrukturalisme, posthumanisme etc, der igen har forskellige måder at begrebsliggøre og udforske deres genstande på. Hvor de først nævnte især beskxftiger sig med den menneskelige agency og diskursivering af verden (se f.eks. Butler 1993) er det i STS, post-poststrukturalisme, post-social konstruktionisme og posthumanisme især "The Parliament of Things" og tingenes væren og handlingspotentiale, der făr plads (se f.eks. Latour 1991; Haraway 1997).

I det udvalg af postpositivistiske tanker, vi som temaredaktører har foretaget, kan det umiddelbart se ud som om, at opgøret med positivismen er lig med poststrukturalisme, diskursanalyse og socialkonstruktionisme. Det er naturligvis ikke tilfældet. Der er mange genealogiske rødder til opgøret med positivismen - faktisk helt tilbage til Kuhns paradigmekritik i 1960erne og vestmarxismens ideologikritik i 1970erne. Også 
strukturalismen nævnes ofte, når opgøret med positivismen skal beskrives, idet den lagde op til et brud mellem tegnet og dets reference i "virkeligheden" - for slet ikke at tale om psykoanalysen og den psykoanalytiske hermeneutik. Alt dette er teorier, der har betydet meget for feministisk teoriudvikling, og som er et integreret led i feministisk positivisme-kritik.

Der findes ikke én postpositivisme, men derimod en mangfoldighed af retninger, der byder ind på dette begreb - og ofte med modstridende eller gensidigt udfordrende bud. Den metodologiske fællesnævner, vi peger på med begrebet postpositivisme, er tanken om, at ingen metodiske greb vil sikre absolut kendskab til den objektive virkelighed eller med andre ord, at det ikke er muligt at indhente Sandheden eller den virkelige virkelighed, blot fordi man udvikler eller raffinerer sine metoder. Fællesnævneren udfordrer tanken om, at Sandheden kan hentes gennem metoden (Truth-throughMethod), der kendetegner mere positivistiske eller realistiske vidensproduktioner.

(Postpositivisme er et metodologisk ${ }^{3}$ begreb i den forstand, at der indtænkes flere videnskabelige områder, men som samtidig ikke lægger sig fast på et bestemt snit, én type teoretisk perspektiv, én type analyseeller indsamlingsmetode osv. Det er perspektiver, der er epistemologisk engageret i en dekonstruktion af fikserede/-erende kategorier og i at undgå lukkede analyser. Fokus ligger således på "det konstruerede og (de-)konstruerende" fremfor "afdrkkede" og "afdækkende".

\section{ANTIVIDENSKAB ELLER \\ ANDEN VIDENSKAB?}

De postpositivistiske antagelser og metodiske greb har en tendens til at vække særlige typer af modstande og spørgsmål. Især poststrukturalisme og social konstruktionisme făr en ganske stor bevågenhed $\mathrm{i}$ form af kritiske indlæg, bøger og konferencer. Det bliver eksempelvis hævdet, at forskere, der benytter sig af postpositivistiske strategier, er ude på berøve videnskabens dens glorie og pille den ned fra piedestalen. Eller sågar at der er tale om anti-videnskab, dvs. en total afskrivning og fornægtelse af, at noget kan kategoriseres som videnskab. Andre hævder, at her er der jo blot tale om absurd relativisme og nihilisme - og mener i den udpegning at finde den ultimative delegitimering $\mathrm{i}$ forhold til at være videnskab. Andre falder særligt over ofte anvendt ord som narrativitet og fortællinger og bekymrer sig for, at strategierne udvikler sig til ren underholdning. Andre igen finder bidragene apolitiske, fordi der ikke indtages standpunkter per se og muligheden for at dekonstruere egne resultater holdes stadig åben.

Det er en bevågenhed og kritik, der inkluderer en bekymring for, at mange isar yngre forskere og studerende lider af den postpositivistiske syge og lader sig inspirere, smitte eller endog forføre af disse "apolitiske", "uvidenskabelige" og "relativistiske" tanker. Som mere etableret forsker må man derfor ikke bare være interesseret i de nye tanker blandt de yngre men derimod forholde sig kritisk og ruste sig mod denne (børne-)syge. Forordet i en antologi om socialkonstruktivisme kan tjene som eksempel på den type bekymring. Redaktørene skriver:

"Kendetegnende for flere af skribenterne i denne antologi er en kritisk holdning til social konstruktivismen. Ikke nødvendigvis social konstruktivismen som helhed, men til de mest radikale udgaver af den. Den kritiske holdning skal ses $i$ lyset af den store tiltrak-ningskraft, som social konstruktivisme $i$ en eller anden form har, specielt blandt yngre forskere"

(Bertilson \& Järvinen 1998, vores kursivering).

Om der er tale om anti-videnskab eller blot en anden type af videnskab afhænger jo ligeledes af, hvad man mener videnskab er, kan eller skal være. Feministiske postpositivister som Patti Lather, Donna Haraway og 
Bronwyn Davies (Lather 1993; Haraway 1997; Davies 1998)4 understreger alle, at deres hensigt ikke er anti-videnskabelig men, at de derimod deltager aktivt som forhandlere af, hvad videnskab kan være. Men de gør det på andre og nye måder, med andre udgangspunkter, andre optikker, andre interesser og andre kriterier end deres kritikere. Og det er måske udfordringen. Kritikerne taler fra et sted diskursiveret gennem bestemte magtforhold. Måske handler det om situeret viden og situerede interesser $\mathrm{i}$ en asymmetrisk relation. Læsere informeret af andre retninger, positioneret på andre måder, tilhørende andre kategorier kan have svært ved at få øje på postpositivisternes kundskabsproduktion som videnskabelig, men det gør den ikke nødvendigvis anti-videnskabelig

Det er, siger Haraway i interviewet her, et historisk-strukturelt problem, at folk på bestemte lokaliserede steder aldrig helt forstår det feministiske bidrag. Det er jo netop deres bud, deres magt og deres position, der udfordres med de postpositivistiske forstyrrelser. Eksempelvis vil feministisk teknoscience altid føles problematiserende eller upassende/skreve (inappropriate, se Minhha 1989) i forhold til de mere Latourske Science and Technology Studies. Om end sidstnævnte også kan karakteriseres som postpostivistiske. Men den feministiske vinkling og interesse er en anden. Det er ikke bare et spørgsmål om at blive politisk, men måske i lige så høj grad, siges det i interviewet, at man kan blive politisk på den forkerte måde, eller med vores ord, at man kan komme til at befolke de forkerte politiske standpunkter.

I debatindlægget "Det farlige og befriende vi" skriver Hee Petersen både med og mod poststruktrualisme, og hun opfordrer til en genlæsning af ældre feministisk litteratur med poststrukturalistiske briller. Hun formulerer, at koblingen mellem metodologi og politik er en central dimension i kvinde- og kønsforskning. Hee Petersen indtænker tidens og især de yngre forskeres store interesse for nytænkende metodologi (som bl.a. herværende nummer af Kvinder, køn \& forskning er udtryk for) i en mere politisk ramme og siger, at det ikke kun er et spørgsmål om at ville lave bedre forskning. Det er i høj grad også en længsel efter (fælles) handling.

Det er Haraways pointe at være politisk "accountable" uden at falde i standpunktsfeminismens fælder og uden at gå i postmodernismens nihilistiske blindgyder. Dvs. at tælle med politisk set. Derfor arbejder Haraway og også Lather med begreber som lokalisering, kropsligggørelse og (priviligerede) perspektiver. Til forskel fra f.eks. forskellige udgaver af standpunktsfeminisme mener Haraway og Lather, at man også skal udsætte sin egen tænkning for dekonstruktion. Man skal ikke tage sine egne analytiske redskaber for at være verden. Så har man kreeret sin egen form for afgudsdyrkelse. Man må derimod huske sig selv på, at ens eget bidrag (også) er et sæt retoriske muligheder, der får konsekvenser.

\section{ANAYTHING GOES?}

"Fears of relativism and its seeming attendant, nihilism or Nietzshean anger, seem to me an implosion of Western, white male, class-privileged arrogance - if we cannot know everything, then we can know nothing." (Lather 1991:116).

Lather syntes allerede i 1991 at være godt træt af beskyldningen om relativisme, denne særlige type delegitimering. Hvad angår relativisme-diskussionen er der efterhånden blevet sagt en del (se f.eks. Parker 1998, Cherryholmes 1988). Relativisme-prædikatet er for os at se et fænomen fra en anden diskurs. En diskurs, der ikke at forglemme fastholder en realisme-relativisme binaritet, fordi den forudsætter, at der er En Sandhed, én realitet, at være relativ til. Der er ét endegyldigt stabilt fundament, som kan og bør findes. Og det er jo netop denne forudsætning som postpositivisterne ikke godtager. 


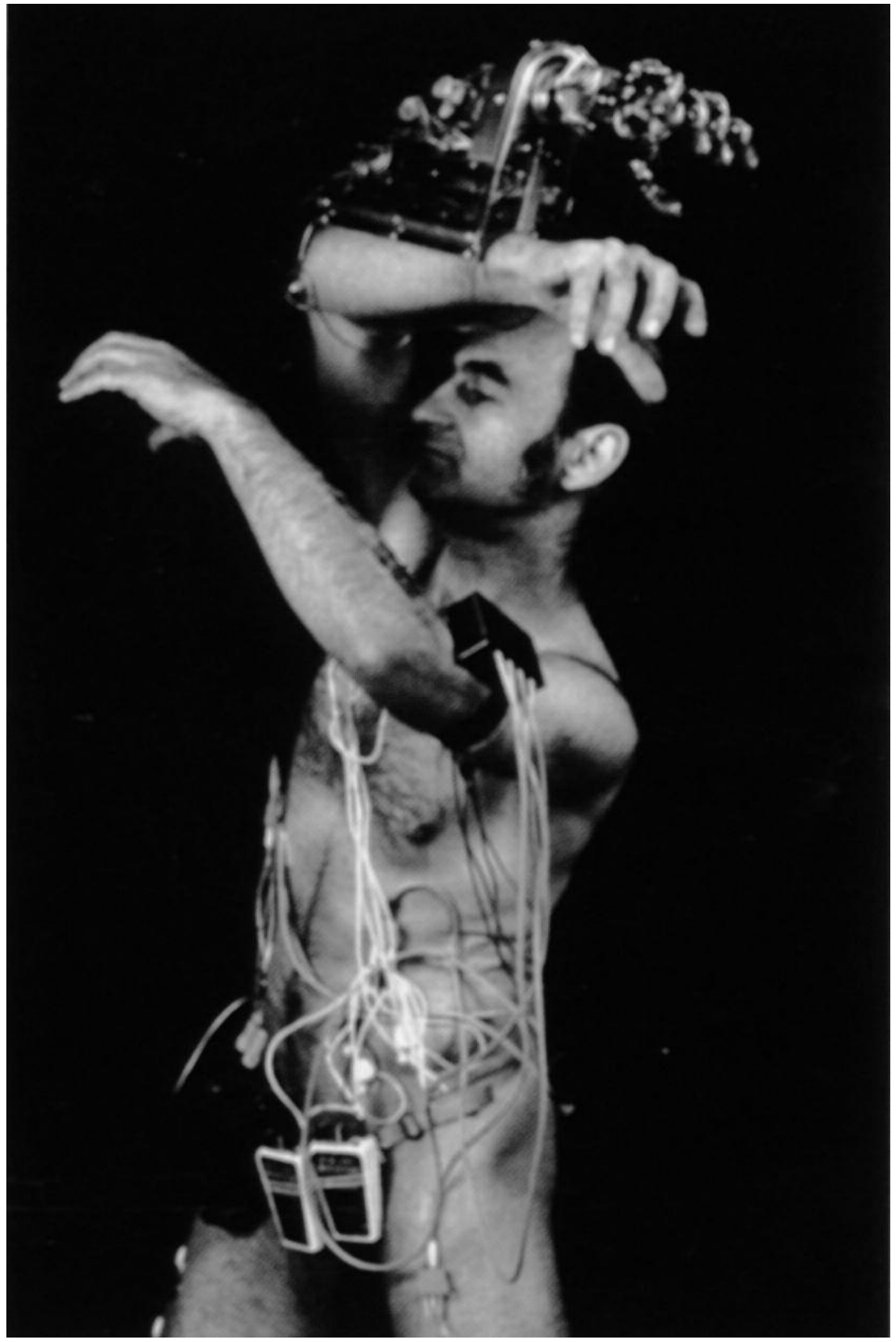

Stelarc: Third Hands Performances, 1992-93. Gengivet med kunstnerens venlig tilladelse 
Imidlertid er det ikke det samme som, at alt er lige gyldigt og lige godt. Eller at vi ikke behøver at engagere os i diskussioner om kriterier for kvalitet og validitet. Tværtimod. Hvad betyder det, når forskere legitimerer deres forskningspraksis som værende f.eks. "sund", "hæderlig"og "redelig". Hvad indebærer det? Er det dekontekstualiserede og universelle størrelser? Eller er det blot laveste fællesnævner, der kan henvise til forskningsrådenes kriterier? I en postpositivistisk kritik vil man overveje betydningen af "hæderlighed" og "redelighed" i forhold hvilken forskningskontekst og hvilke typer af magtmekanismer, sprog og teknologier, der er på spil. Postpositivistisk forskning kendetegnes ved, at man lytter til, hvilke udgaver af kundskabsproduktion, der finder vej til kategorien 'videnskab'. Med andre ord er man optaget af at undersøge, hvordan noget bliver til videnskab. Man spørger til de betingelser, der gør at noget udpeges som videnskabeligt og andet som ikke-videnskabeligt, uvidenskabeligt eller pseudovidenskabeligt etc .Og man undersøger hvilke konsekvenser den type in- og eksklusionsprocesser har. Dvs. hvilke epistemologiske retninger, genstandsfelter, spørgsmål, resultater og forskersubjekter etc. går an og hvilke går ikke an. Hvordan gør de det og hvornår? Postpositivistiske refleksioner bygger på en interesse for de betydningssystemer og de magt/vidensrelationer, der på forskellige måder både muliggør og begrænser kundskabsproduktion og på den måde synliggør, at kategorien 'videnskab' ikke er stabil, men derimod kontingent, til forhandling og magtbærende/-konstituerende.

Postpositivismens påstand er således, at der er altid indlejret politiske og etiske problemstillinger i det metodologiske valg: Fra definering af undersøgelsesgruppe, over valg af metoderedskaber til f remstillingsformen. Der er altid andre opregninger, andre hensyn, andre muligheder. Men de valg, man træffer, har en kontekstuel indlejret begrundelse og ligeledes en betydning for det, man ser, og for det man kan gøre med det, man ser. Sociologen og feministen Laurel Richardson udtrykker sit kvalitetetskriterium med ordene "because it suits me". Richardsons vending kan ses som et rent subjektivt kvalitetskriterium, hvilket hun selv gør en dyd ud af at fremhæve. Hun gør, hvad hun gør, fordi det passer til netop hende. Men sætningen kan også tolkes på den måde, at det, der netop passer os, signalerer noget om beskaffenheden af vores respektive situerethed, positionering og kropsliggørelse. Det udsiger noget om genkendelighed og selvfølgelighed set fra bestemte steder. Og det fortæller noget om inadækvans, andethed og skævhed set fra bestemte steder og dermed om en anden type af objektivitets- og kvalitetskriterier (jf. diskussionen ovenfor om hvem, der føler sig udfordret, og hvem der føler sig genkendt i de postpositivistiske bestræbelser).

Når det universelle legitimeringsgrundlag og indforståetheden om, at 'vi' alle ved, hvad god og gyldig videnskab er, forsvinder, bliver det påtrængende at forholde sig nysgerrigt til spørgsmål om validitet og kvalitet kontinuerligt. Og det er præcis der i den kontinuerlige nysgerrighed, at man aner konturerne til et bud på postpositivistisk videnskabelig kvalitet: Der er ikke nogle færdigpakkede (lette) løsninger, der sikrer og garanterer 'objektivitet' som forskeren ureflekteret kan reproducere. Ansvaret for, at forskningen er god og gyldig må konstant gøres til genstand for refleksion. I alle kundskabsproduktionens afsnit.

\section{ET SPØRGSMÅL OM KUNDSKABSAMBITIONER}

Postpositivisme medfører ikke automatisk et greb ned i den kvalitative værktøjskasse. Postpositivisme siger andet og mere end den udelukkende metodiske afgrænsning, der ligger i benævnelsen 'kvalitativ'. Positivisme er ikke det kvalitatives binære anden. Der udøves som bekendt megen kvalitativ 
forskning, der mere eller mindre eksplicit reproducerer de positivistiske videnskabskriterier. I artiklen af Inge Henningsen og Dorte Marie Søndergaard udføres der også kvantitativ forskning, der fraviger positivistiske kvalitetskriterier. Henningsen og Søndergaards artikel er produktet af en umiddelbar umage hybrid. En matematisk statistiker og en kvalitativt orienteret psykolog har overskredet deres fagtraditioner og bidrager derigennem med en nytænkning af såvel grænser for som kategorisering af forskningsmetoder. Henningsen og Søndergaard foreslår, at demarkationslinjen flyttes fra feltet mellem kvantitativ og kvalitativ forskning til skellet mellem empirisk forskning og eksperimentel forskning. Artiklen er et opgør med enten-eller kategorier og bringer diskussionen om metoder fra et overfladisk metoderedskabsniveau til overvejelser af de metateoretiske dispositioner. Forskellighederne har ikke rod i selve metoderedskabet, men derimod af de kundskabsambitioner som redskaberne er valgt på baggrund af. Det er snarere en metateoretisk forskel frem for et spørgsmål om metodeværktøjer.

\section{KREATA, ANALYSE OG \\ INDSAMLINGSREDSKABER}

Indenfor en postpositivistisk tænkning er det såvel epistemologisk som ontologisk underforstået, at man ikke kan finde den objektive virkelighed. Det er ikke muligt at frembringe universelle teorier, der udtømmende kan forudsige eller endeligt beskrive den virkelige virkeligheds virkemåder og effekter. Man kan ikke per procedure og metode afdække og nå den "virkelige virkelighed" - selvom man anstrenger sig hårdt og længe.

Det er en ofte brugt vending i postpositivistisme, at hverken datamateriale eller analyser er uskyldige, men derimod forurenede af hinanden. Hos nogle postpositivistisk inspirerede forskere vil man se, at spaltepladsen især er optaget af en poststruktu- ralistisk forstyrrelse af ontologisk essentialisme og af tankefigurer om, at begreber og kategorier transformerer substansen og dermed er med til at etablere det, vi forsker i. "Data" er altså konstrueret gennem diskursen. Lather taler med henvisning til Judith Butler om, at man ikke skal opgive sit videnskabelige forhavende, fordi representationen er i krise, men derimod bygge videre på ruinerne af de idealer, der lå i den tænkning.

Hos andre som f.eks. Haraway er det især en post-poststrukturalistisk dekonstruktion af den epistemologiske rationalisme og universalisme, der er omdrejningspunktet. Den uforurende virkelighed findes ikke og kan derfor ikke re-præsenteres, siger poststrukturalisterne. Og post-poststrukturalisterne tilføjer, at virkeligheden derimod kan artikuleres fra bestemte steder med netop disse bestemte steder som en del af eller forudsætning forvirkeligheden.

Wendy Stainton-Rogers (2000) foreslår i forlængelse af den diskussion, at begrebet "data" erstattes med en ny sproglig konstruktion "kreata". For os at se understreger kreata-begrebet en udfordring på to fronter: En udfordring af epistemologisk rationalisme og universalisme og af ontologiske essentialisme. Data siger noget, men de er aldrig bare passive givne, oprindelige størrelse, der ligger derude og venter. De "medskabes" og anvendes af forskere (og andre aktører), der er teoretisk informerede på bestemte måder og som har interesser, lidenskaber og politikker. Ofte anvender forskere vendinger som "data viser" eller "som det fremgår af data", men vores pointe er, at data aldrig siger noget i sig selv. Kreata bliver altid til i særlige kontekster i samarbejde mellem forskellige aktører, spørgsmål og teknologier. I den forstand er kreata hverken rene data eller ren tekst.

I interviewet med Donna Haraway husker hun på, at heller ikke de kategorier, som vi bruger til at begrebsliggøre fænomener 
med, er transparente eller frosne. "It matters which categories you use to think other categories with". Man bruger kategorier til at tænke med og til fiksere verden med. Kategorier er med at stabilisere mening i bestemte former fremfor andre. Kategorier kan bruges til at problematisere andre kategorier med, til at lade dem afbryde og forstyrre hinanden, til at skrue op og ned for volumen, til at skifte for- og baggrunde. Det at stabilisere verden i mening er en materiel praksis. Kategorier er materielle teknologier. Kategorier er tænketeknologier, der gør noget ved verden og dermed ikke bare idealistiske fænomener. Kategorier har materialitet, effektivitet og er virksomme.

Pointerne om kategorier, som jo er en slags analysemetoderedskaber, gør sig i vid udstrækning også gældende for såkaldte indsamlingsredskaber som f.eks. observation, interviews eller fotografering. Om kreata materialiseres i skreven, oral eller visuel form har stor betydning for hvilke genstandsfelter og fokuseringspunkter, der bliver aktuelle. Når forskeren således gør en smule "retooling", som Haraway kalder det, vil der også her betyde en ændring i hvad forskeren får øje for/på. Som eksempel kan nævnes den store hvor stor betydning artefakter og kroppe har fået i Staunæs' projekt om etnicitet og køn qua et (kreata-) billedemateriale skabt i samarbejde med børn. Kroppene og artefakternes betydning ville sandsynligvis have være mindre synlige og dermed mindre belyst, hvis metoderedskabet udelukkende havde været interviews (se Staunæs 2000a; 2000b).

Hverken kategoriteknologier eller redskabsteknologier må for os at se gøres transparente $\mathrm{i}$ forhold til forskningsprocesser og -produkter. Snarere skal de gøres tykke og synlige og dermed mulige at medreflektere. På den ene side har det altså en analytisk pointe, at kategoriarbejdet kan høres og ses. At deres friktion med materialet kan føles. Men på den anden side må de også være gennemsigtige på et vist sæt, ellers låser man sig fast og blokere for den vi- derekommunikation med såvel materialet som omverden. Man må derfor tænke taktisk over valget af kategorier, metoderedskaber og analytiske strategier og beslutte hvornår man fremhæver, og hvornår man underkommunikerer kategori- og redskabsarbejdet. Det vil vi vende tilbage til under afsnittet "Den komfortable tekst under pres”.

\section{FORSKERSUBJEKTETS TILBLIVELSER}

Indenfor postpositivisme bliver det vigtig at undgå det såkaldte gudetrick og se "det hele lidt fra oven” (Haraway 1991). I stedet må man situere sig selv og sin kundskabsproduktion og erkende sin egen partialitet.

Den diskussion dukker særligt op i Patti Lathers artikel "Against Empathy, Voice and Authenticity". Lather skriver, at forskeren som vidensproducent må afskrive sig rollen som Herre over Sandhed og Retfærdighed. Rollen som Den store Fortolker (se også Lather 1991) med særlige adgange og redskaber til at proklamere den Sidste Sandhed. I stedet vil Lather skrive en "såret forsker" frem. Forskeren må opgive sine egen heroisme men uden at romantisere de udforskedes stemme. I forhold til diskussionen om at berøve videnskaben dens glorie og pille den ned fra piedstalen, signalerer Lathers manøvre, at videnskabsproduktioner ikke er ophøjede og hellige meningsskabelsesprocesser. Samtidig har hun blik for den betydning denne særlige type aktivitet historisk og kulturelt bliver og er blevet tillagt, netop som noget ny-guddommeligt. Men spørgsmålet om hvorvidt "glorieafpilningen" af videnskaben og forskeren er noget bekymringsvækkende eller ej afhænger naturligvis af ens videnskabelige og politiske interesser. Ønsker man at videreføre eller destabilisere forestillingen om 'det ophøjede og hellige' ved den videnskabelige virksomhed?

I forskellige postpositivistiske projekter har tanken om den sårede og partielt informerede forsker ført til en interesse $i$ at ind- 
drage de/det udforskede som medforskende. En tendens der ligger i f.eks. aktionsforskning, praksisforskning og dialogisk forskning, men som vi af pladsmæssige grunde ikke har inkluderet i dette nummer af Kvinder, køn \& forskning.

For antropolog Cathrine Hasse får forskerens situeringsmanøvre en særlig metodologisk konsekvens. I Hasses artikel åbnes op for, at forskersubjektet undersøger sin egen tilblivelse og bruger denne refleksion til at udsige noget om det felt, hun forsker i. På baggrund af et empirisk projekt omkring (kønnede) læreprocesser blandt fysikstuderende diskuterer Hasse, hvordan hendes kønnede forskerpostion gav anledning til videnskabelig refleksion. Observation er et ofte benyttet metoderedskab i antropologien, og Hasse argumenterer for, at den observerende forsker er deltager og ikke bare en flue på væggen i det felt, der udforskes, og at denne deltagelse er forbundet med en positioneret kulturel læreproces, hvor tidligere viden og positioner overskrides. Inspireret af bla. Haraway formulerer Hasse, at viden er situeret, og at den eneste mulige form for objektiv viden, er den situerede viden. For forskeren gxlder det om, skriver Hasse, at blive bevidst om sit eget "somewhere" og at bruge såvel processeringen som positioneringen $\mathrm{i}$ forskning til at fortælle om det, der forskes i. Man er endvidere nødt til at forholde sig til de sociale kategorier, der arbejder i feltet. Eller måske mere præcist, der er en pointe med at reflektere over, hvad det i givet fald vil betyde, hvis forskeren overskrider feltets sociale kategorier. Det er således ikke den personlige og dekontekstualiserede viden, Hasse fylder på sit forskersubjekt, men derimod en viden, der er affødt af deltagelse og positionering som netop kønnet forsker i feltet.

\section{DEN KOMFORTABLE TEKST UNDER PRES}

Hasses forskersubjekt er blevet diskursiveret gennem en deltagelse i det undersøgte felt, fysikkens. Det afspejler sig også i hendes antroplogiske sprog, der udvides med begreber hentet i fysikkens terminologi som f.eks. vektorale læreprocesser. Det giver hendes stof helt nye vinklinger.

Men skribenter, der trækker på postpositivisiske forståelsesmåder, skriver ofte i et særligt sprog, hvor ordene bruges på nye måder og ikke bare kan tages for pålydende. Bruger man f.eks. en poststrukturalistisk optik, kan man benytte sig af skriftsproget meget aktivt ved at fremmedgøre sproget og ved at gentage det, man lige har sagt men med andre mere koncise vendinger. Gentagelse, eksotisering, detaljeforstørrelse og detaljeminimering er således gennemgående principper. Det kan ved første øjekast virker fremmedgørende og distancerende (ja undertiden irriterende) Men ideen er, at de sproglige finurligheder (og også fremmedgørelse og distance) kan have en central funktion i relation til at præsentere problematikker på en ny måde (se også Søndergaard 2000a). Som når f.eks. Søndergaard (1996) udskifter begrebet kvinde med "kvindeligt kropsmærket" for at afnaturalisere kønnet. Eller når etnicitets- og kønsforskeren bell hooks skriver sit navn med småt for at pege på sammenhænge mellem navn, racialisering og kolonisering.

I tråd med tankerne om at fremstillingsformen er med til at "gøre" kreata og genstandsfeltet benytter en del postpositivistisk informerede forskere sig af alternative genre $\mathrm{i}$ formidlingen af deres forskning. Et eksempel på overskridende videnskabelig tekstskrivning står feministen Laurel Richardson for, som indkredser sine sociologiske pointer ved at skrive dramaer, digte og autobiografiske tekster (se f.eks. Richardson 1997). Et andet eksempel er Trinh Minh-ha (1989), der supplerer det skrevne med visuelle udtryksmidler.

Formidlingsstilen hænger således sammen med et politisk og epistemologisk engagement $\mathrm{i}$ at overskride gamle tankebaner 
og at gøre det relativt sværere at fiksere den endelig mening. I interviewet med Nina Lykke et al. diskuterer Haraway, hvordan hun nedbryder barrierne mellem en mere litterær, intuitiv skrivemåde og så en mere traditionel teoretisk måde at skrive på. Haraways pointe er, at ikke kun hendes tekst men videnskabelige arbejder som sådan er litterære og benytter sig af forskellige retoriske redskaber.

Fremfor Pixiebogsgenren foretrækker Haraway tekster i mange lag, med mange noter og et stort arkiv. Hun vil, som Lather, gøre oprør mod Klarhedens Tyranni og undgå den systematiske totalitet ved at skrive tekster, der spørgsmålstegn ved sig selv.

Som antydet bevæger også Lather sig ind i en diskussion af forskersubjektets forhold til de(t) udforskede i artiklen med den provokerende titel "Against Empathy, voice and authenticity”. Også Lather opfordrer til gentænkning af den videnskabelige fremstillingsform og dens tekstuelle virkemidler. Lather udfordrer feministiske mærkesager som at give stemme, at gå efter empatien og at finde autenticiteten. Det har været vigtige modstrategier i forhold til den etablerede videnskabelighed, skriver Lather. Men der er en fare for, at det kan udvikle sig til en ny isme, der lukker sig om sig selv og ikke reflekterer sine egne naturaliseringer men derimod reproducerer nye ikke-situerede sandheder ukritisk.

Hos Lather bliver forskningen nu, noget der overraskes af forskelle i perspektiver og praksisser. Det at give stemme til de stemmeløse er en særdels problematisk affære pga. muligheden for at manipulere og risikoen for at forråde. Lather afviser derfor den for lette identitikationsform, der ofte forekommer i Den personlige Historie. Det er en tendens, der kommer tydeligt til udtryk i f.eks. talksshows og andre medieprodukter, hvorfor Lather andetsteds har kaldt det ophradisering med henvisning til det amerikanske talkshow med Ophra Winfrey.
Lather frabeder sig den konformtable tekst, der serverer de udforskede som letspiselige og fordøjelige cases. Ligesom hun afskriver den tekst, der implicerer et validitets- og kvalitetskriterium bygget på tårer og medfølelse (the validity of tears). Viljen til at "forstå" den Anden er ikke bare en humanistisk, universel venlighed. Den kan også forstås som en ny måde at indoptage og absorbere den Anden, hvorved denne Anden igen forsvinder og bliver ligesom "os". Det betyder, at den form for empati snarere er med til at cementere diskriminerende strukturer fremfor at afvikle dem.

\section{DEKOLONISERING AF TEKSTEN}

En stor del af de postpositivistiske, metodiske bestræbelser har rettet sig mod at artikulere $\operatorname{de}(\mathrm{t})$ udforskedes stemme og på at etablere dialog mellem forsker og udforskede. Men bestræbelserne på dekolonisering har en tendens til at forsvinder i den videnskabelige tekst. Eller med andre ord, forskelligheden i perspektiver og positioner kommer ikke frem i teksterne. I de videnskabelige produkter synes forskelle og afstande derimod at kollapse $\mathrm{i}$ en totalitet, hvor såvel forsker som (forskellige) udforskede forsvinder. Forskning udmunder ofte i konsensus-tekster, hvor der fremfor en kakafoni af stemmer, der debatterer et emne, optræder et nærmest enstemmigt kor, der synger "And so say all of us" - dirigeret af forsker-forfatteren (se Condor 1997). Metoderne dekoloniseres men den videnskabelige fremstillingsform opretholder en ureflekteret kolonisering af de(t) udforskede.

Med henvisning til en række tekster, der baserer sig på dialogisk forskning men munder ud i monologiske tekster skriver social konstruktionisten Susan Condor (ibid.), at der er omsonst at forsøge sig. Man kan lige så godt droppe det. Men fremfor at ende i den type handlingslammelse Condor indtager, foreslår Lather den usamarbejdsvillige, ikke-kooperative tekst, der bygger på en kløft mellem tekst og læs- 
er. Lathers bud er skrive videnskabelige tekster i de "rodede mellemrum" ("the messy spaces in between"). Det betyder, at både forsker og udforskede udtrykker sig i teksten som netop forsker og udforskede, og at forskelle i positioner og perspektiver viser sig i den videnskabelige teksts opbygning. Fremfor et "mod" empati, stemme og autencitet argumenterer Lather snarere for en forskning og en forskningtekst, der balancerer mellem på den ene side forskerheltinde, der udelukker og deautoriserer de udforskede og på den anden side en romantisering og assimilering af de Andres stemme (Staunæs 2000b). Lathers bud er split-tekster. Dvs.en dekolonisering af teksten, hvor den situerede viden og det situerede perspektiv fremhæves som viden og perspektiv fra et "somewhere" og ikke fra et "nowhere". Et eksempel kan være Lathers eget forsøg, hvor de interviewedes udsagn står på den $ø$ vre del af siden og forfatternes analyser og refleksioner på den nedre halvdel (se også Lather \& Smith 1997).

\section{Traditionelle GREB SOM POSTPOSITIVISTISKE STRATEGIER}

Problemet i forhold til de litterære, poetiske og mangefacetterede tekster er desværre, at forfatterne ofte ikke genkendes / anerkendes i det "rigtige selskab"og dermed bliver tandløse i al deres bidskhed. Det er et paradoks, at man på den ene side vil overskride uønskede eller begrænsende prakssisser og forståelser, men på den anden side må gøre det indenfor netop det samme diskursive repertoire.

Ved læsning af såvel Henningsens og Søndergaards artikel (og til dels Lathers bidrag) til dette metodenummer undrede vi os over, at teksterne var skrevet i et meget depersonaliseret sprog, hvor deres respektive forskningsretninger, -positioner og -perspektiver enlarges 5 , dvs. forstørres gennem ord som f.eks. "den sociokulturelle empiriske forskning" fremfor, at det skrives frem som netop kontekstualiserede og situerede praksisser, som (de to ovenikøbet forskellige) forskersubjekter Henningsen og Søndergaard varetager (en kritik man til dels også kan rette mod nærværende tekst). I Henningsens og Søndergaards artikel er det et andet forsker- og forfattersubjekt, vi møder end i f.eks. Hasses artikel. Hvor Hasses forfattersubjekt træder frem i jegform og bruger sin egen subjektivering eksplicit, glider Henningsen og Søndergaard ind i en mere ubemærket, næsten gennemsigtig forfatterposition. Vi undrede os også over, at det stærke og magtfulde sprog, det sprog der hører positivismen til, på en eller anden måde kom til at vinde og dominere teksten. Der tales f.eks. om resultater, om data osv. Begreber, der sætter tegn om en anden forskningstradition end den, vi som redaktører forbandt artiklens metateoretiske overvejelser med. Vi fundrede med andre ord over artiklens overleveringer af mere traditionel forskning, og at den ikke "gik hele vejen".

Men hvis artiklen skal have gennemslagskraft eller blot læses indenfor de mere traditionelle etableringer af såvel matematikken som psykologien skal dens pointer formidles i et sprog, der gør den genkendelig og legitim. Havde Henningsen og Søndergaard formuleret deres pointer med dialogens, dramaturgiens eller poesiens virkemidler, ville artiklen øjensynligt være upassende og skæv indenfor en række videnskabelige bastioner, som forfatterne gerne ville i dialog med. Eller formuleret på poststrukturalistisk den for dekonstruerende, for eksotiserende formidlingsform er ikke intersubjektiv genkendelig indenfor de videnskabelige traditioner, der benytter sig af det stærke sprog og en transparent skrivestil, hvor forskningssubjekter og -objekters konstruktion tones ud af den videnskabelige virkelighed og fremstilling.

Fra en postpositivistisk platform kan man altså benytte sig af en umiddelbart ikkeoverskridende formidlingsstrategi. Man kan vælge at fortsætte i en bestemt genre og derigennem få gennemslagskraft indenfor 
forskningstraditioner, hvor den genre er værdisat og funktionel. Det handler altså ikke bare om at få stemme i slaget om, hvad der er videnskab, men om at bruge sin stemme på en måde, der kan høres af ører, der er tunet ind på en bestemt kanal. Og dermed går Henningsen og Søndergaard måske hele vejen ved at bruge traditionelle greb som postpositivistiske strategier.

\section{DET POSTPOSITIVISTISKE MULTIVERS}

Vi ved ikke, om det med dette temanummer af Kvinder, køn \& forskning er lykkedes os at tune ind på andre kanaler end vores egne. Det håber vi. Vi håber, at nummeret stimulerer dialogerne om, hvad videnskab og videnskabelige metoder også kan være. De tekster, der bringes her, er hovedsageligt udviklet indenfor kønsforskningen, men der har været og er en tilsvarende interesse for overskridende metoder indenfor andre felter, f.eks. i etnicitetsforskningens diskussion af dekoloniserende metoder (se f.eks. Smith 1999). Der er ikke længere blot kvinderne, der er "outsiders within" men i høj grad mennesker med etnisk minoritetsbaggrund, og det er måske her eller i "de rodede mellemrum" mellem etnicitetsog kønsforskning" at en del metodisk nytænkning kommer til at foregå.

Men overskridende metoder kan være farlige. De udfordrer etablerede magtbalancer og autoriteter. Der kan være en pointe i ikke at overskride for meget. Som Haraway siger, er det spørgsmålet, om man kan leve med spændingerne og friktionerne, det ukomplette og det partiale som bekræftelser snarere end som byrder. Vi tilføjer, og om de, man vil have i tale og høres af, kan leve med det.

Velkommen til et udsnit af det postpositivistiske multivers.

\section{Noter}

1. Temanummeret om overskridende metoder er redigeret af Dorthe Staunæs i samarbejde med Eva Bendix Petersen og Pernille Tanggaard Andersen. 2. For en dansksproget introduktion til Lather se Mørck 2000. En dansksproget introduktion til Haraway se Lykke 1996; 1999

3. Metodologi anvendes her som betegnelse for sammenhænge mellem epistemologi, teori, metoderedskaber, analytiske strategier og fremstillingsformer.

4. For en dansksproget introduktion til Davies se Søndergaard 2000b.

5. Se Condor 1997 for andre finurlige men ganske virkningsfulde måder at forstørre sig selv og udvide sin virkningsfuldhed på, f.eks. ved at opliste en række referencer på anerkendte forfattere, der støtter ens synspunkt.

\section{LITTERATUR}

- Bertilson, Margareta \& Margareta Järvinen (1998): “Indledning”, i Järvinen, Margareta \& Margareta Bertilson (red): Social konstruktivisme. Bidrag til en kritisk dialog. Hans Reitzels Forlag. København.

- Butler, Judith (1993): Bodies that matters. On the discursive limits of "sex", Routledge, London.

- Cherryholmes, Cleo (1988): Power and Criticism: Poststructural Investigations in education, Teachers College Press, New York.

. Condor, Susan (1997): “And so say all of us", i Ibáñaz, Thomas \& Lupicinio Friguez (ed): Critical Social Psychology, Sage, London.

- Davies, Bronwyn (1998): "Psychology's subject: A commentary on the Relativism/Realism Debate", i Ian Parker (ed): Social constructionism, Discourse and Realisme, Sage, London.

- Lather, Patti (1991): Getting smart-feminist Research and Pedagogy with/in the postmodern, Routledge, London \& New York.

- Lather, Patti (1993): "Fertile Obsession - Validity after Poststructuralism", i Sociological Quaterly, vol. 34, no 4, p. 673-693, JAI Press.

- Lather, Patti \& Chris Smith (1997): Troubling the Angels. Women living with HIV/AIDS. Westview Press, Oxford.

Lykke; Nina (1996): “Kyborg eller gudinde. Feministiske dilemmaer i det sene 20.århundredes økoog teknokritik", i Kvinder, køn \& forskning nr 4. - Lykke, Nina (1999): "En postkønnet eller kvindelig cyberkultur", i Kvinder, køn \& forskning nr 2. 
· Haraway, Donna (1991): "Situated knowledges: The Science question in Feminism and the Privilige of Partial Perspective", i Haraway, Donna: Simians, Cyborgs, and Women. The Reinvention of Nature, Free Association Books, London.

· Haraway, Donna (1997): Modest_witness@Second_Millennium.FemaleMan@__Meets_OncoMou$s^{\mathrm{TM}}$. Feminism and Technoscience, Routledge, London.

- Latour, Bruno (1991): We have never been modern. Harvester Wheatsheaf, New York.

- Minh-ha, Trinh (1989): Woman, Native, Other. Writing Postcoloniality and Feminism, Indiana University Press, Bloomington and Indianapolis. - Mørck, Yvonne (2000): “Magt og vidensproduktion. Yvonne Mørck introducerer Patti Lather", i Kvinder, køn \& forskning nr $\mathrm{l}$.

- Parker, Ian (1998): Social Constructionism, Discourse and Realism, Sage Publications, London.

- Richardson, Laurel (1997): Fields of play. Constructing an Academic Life, Rutgers University Press, New Brunswick \& New Jersey.

- Smith, Linda Tuhiwai (1999): Decolonizing Methodologies. Research and Indigenous People, Zed Books Ltc, London \& New York.

- Stainton-Rogers, Wendy (2000): "Why some Women don't iron and some older men make better lovers", paper på konferencen Understanding the Social World 2, University of Huddersfield.
- Staunæs, Dorthe (2000a): "Engangskameraer og børneblikke”, I Schulz-Jørgensen, Per \& Jan Kampmann (red): Børneperspektiver og børn som informanter, Børnerådet, København.

- Staunæs, Dorthe (2000b, in press): "Engangskameraer som dialogisk metoderedskab eller teknologisk fix", i Christrup, H. et al (red): Metodiske tilgange i kommunikationsforskning (arbejdstitel). Roskilde Universitetsforlag. Roskilde.

- Søndergaard, Dorte Marie (1996): Tegnet på kroppen. Køn: Koder og Konstruktioner blandt Unge voksne i Akademia, Museum Tusculanum, København.

- Søndergaard, Dorte Marie (2000a, in press): "Destabiliserende diskursanalyse", i Haavind, Hanne (red): Kjønn og Fortolkende Metode. Gyldendal Akademisk. Oslo.

. Søndergaard, Dorte Marie (2000b): "Kønnet subjektivering. Dorte Marie Søndergaard introducerer Bronwyn Davies", i Kvinder, køn \& forskning nr 1 .

Dorthe Staunæs er cand psych. og ph.d-stipendiat ved Institut for kommunikation, journalistik og datalogi, Roskilde Universitetscenter.

Eva Bendix Petersen er cand.mag. i historie og psykologi og ph.d.-stipendiat ved Sociologisk Institut, Københavns Universitet. 